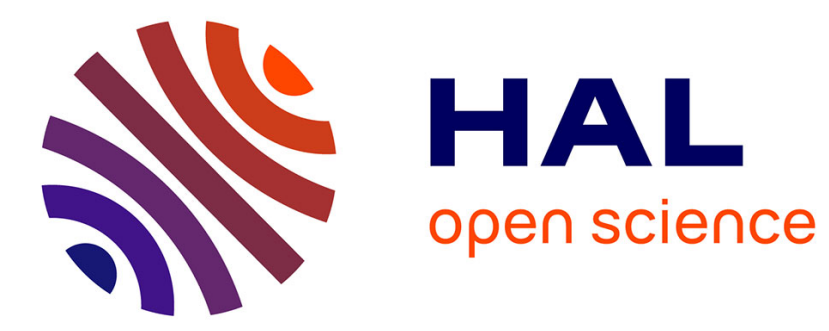

\title{
High activity of mononuclear copper present in the framework of CuSiBEA zeolites in the selective catalytic reduction of $\mathrm{NO}$ with $\mathrm{NH} 3$
}

\author{
Rafal Baran, Teresa Grzybek, Thomas Onfroy, Stanislaw Dzwigaj
}

\section{To cite this version:}

Rafal Baran, Teresa Grzybek, Thomas Onfroy, Stanislaw Dzwigaj. High activity of mononuclear copper present in the framework of CuSiBEA zeolites in the selective catalytic reduction of NO with NH3. Microporous and Mesoporous Materials, 2016, 226, pp.104-109. 10.1016/j.micromeso.2015.11.065 . hal-01263831

\section{HAL Id: hal-01263831 \\ https://hal.science/hal-01263831}

Submitted on 18 May 2016

HAL is a multi-disciplinary open access archive for the deposit and dissemination of scientific research documents, whether they are published or not. The documents may come from teaching and research institutions in France or abroad, or from public or private research centers.
L'archive ouverte pluridisciplinaire HAL, est destinée au dépôt et à la diffusion de documents scientifiques de niveau recherche, publiés ou non, émanant des établissements d'enseignement et de recherche français ou étrangers, des laboratoires publics ou privés. 
High activity of mononuclear copper present in the framework of CuSiBEA zeolites in the selective catalytic reduction of $\mathrm{NO}$ with $\mathrm{NH}_{3}$

Rafal Baran ${ }^{1,2,3}$, Teresa Grzybek ${ }^{1}$, Thomas Onfroy ${ }^{2,3}$, Stanislaw Dzwigaj ${ }^{2,3, *}$

${ }^{1}$ Faculty of Energy and Fuels, AGH University of Science and Technology, Al. A. Mickiewicza 30, 30-059 Krakow, Poland

${ }^{2}$ Sorbonne Universités, UPMC Univ Paris 06, UMR 7197, Laboratoire de Réactivité de Surface, F-75005, Paris, France

${ }^{3}$ CNRS, UMR 7197, Laboratoire de Réactivité de Surface, F-75005, Paris, France

Figures: 9

Table : 1

Keywords: Copper, BEA, SCR, $\mathrm{NO}, \mathrm{NH}_{3}$

*Corresponding author:

Dzwigaj Stanislaw, e-mail : stanislaw.dzwigaj@upmc.fr, tel : 33144272113 


\begin{abstract}
$\mathrm{Cu}_{\mathrm{x}} \mathrm{SiBEA}$ zeolites (with $\mathrm{x}=1-7.5 \mathrm{Cu}$ wt $\%$ ) prepared by a two-step postsynthesis method which consists in the first step of dealumination of parent BEA zeolite to obtain aluminumfree SiBEA support and then in the second step, of contacting the obtained material with an aqueous solution of copper nitrate, were used in this work as catalysts of SCR of NO with ammonia. XRD, TPR and FTIR investigations showed that up to 2 wt $\%$ of $\mathrm{Cu}$ was successfully incorporated into zeolite beta structure as framework mononuclear $\mathrm{Cu}(\mathrm{II})$. The FTIR of pyridine sorption revealed that the incorporation of copper into zeolite framework led to the creation of new Lewis acidic sites which were responsible for high activity of $\mathrm{Cu}_{\mathrm{x}} \mathrm{SiBEA}$ zeolite catalysts in SCR of NO with ammonia. The catalytic activity of $\mathrm{Cu}_{\mathrm{x}} \mathrm{SiBEA}$ in SCR of NO with ammonia used as a reducing agent strongly depends on the nature and environmental of copper in BEA structure. The $\mathrm{Cu}_{1.0} \mathrm{SiBEA}$ catalyst with predominantly framework $\mathrm{Cu}(\mathrm{II})$ was the most active and selective among the tested samples in wide temperature range. In contrast, the application of $\mathrm{Cu}_{\mathrm{x}} \mathrm{SiBEA}$ zeolite catalysts with higher $\mathrm{Cu}$ content (> than 2 wt $\%$ of $\mathrm{Cu}$ ) containing a mixture of framework and extra-framework $\mathrm{Cu}$ (II) resulted in low NO conversion in SCR at high temperature range, as well as, the high concentration of undesired $\mathrm{N}_{2} \mathrm{O}$ in outgas stream. It indicates that octahedral $\mathrm{Cu}$ (II) and/or copper oxides present in extra-framework position of SiBEA zeolite promote at high temperature ammonia oxidation.
\end{abstract}




\section{Introduction}

Selective catalytic reduction of $\mathrm{NO}_{\mathrm{x}}$ with ammonia is a widely applied method of nitric oxides removal from exhaust of power plants [1, 2]. It is also of interest for the treatment of $\mathrm{NO}_{\mathrm{x}}$ emissions from heavy duty diesel engines [3, 4]. In case of stationary sources, the standard $\mathrm{SCR}$ catalyst is $\mathrm{V}_{2} \mathrm{O}_{5} / \mathrm{TiO}_{2} / \mathrm{MnO}_{3}$. However due to its narrow temperature window it cannot be applied for mobile sources. Moreover, conventional three way catalysts are not able to remove $\mathrm{NO}_{\mathrm{x}}$ from diesel engine because of oxygen over abundance. Thus, other types of catalysts are intensively studied, in order to find the most efficient one. Among the many tested candidates [5-7], the most promising are zeolite-based materials promoted with transition metal ions such as $\mathrm{Cu}$ and/or Fe [8-11].

Many researches indicated isolated metal ions in exchanged positions as active species responsible for high NO conversion and excellent $\mathrm{N}_{2}$ selectivity. Xue et al. [12] concluded that $\mathrm{Cu}^{2+}$ ions displaced into cavity of SAPO-34 are responsible for high activity at low temperature. However, Pereda-Ayo et al. [13] observed that isolated $\mathrm{Cu}(\mathrm{II})$ ions located in pores of BETA and ZSM-5 zeolite maintained $\mathrm{NO}_{\mathrm{x}}$ conversion at high temperature range. Additionally, there are still a lot of questions to answer about reaction mechanisms and the formation of by-products from competitive reactions of ammonia oxidation.

Others very important factors for potential catalysts application on industry scale are their stability and durability. It is well known that zeolite materials may be damaged by hydrothermal treatment resulting in dealumination [14], crystalline structure disordering [15] or metal ions migration $[16,17]$. In order to avoid such effects and retain catalytic properties for a long time, improvements in catalyst synthesis or post-synthesis modification are proposed. One of the such proposal way was the application of materials with CHA zeolite structure which seemed to be more resistant to steam than large pores zeolites $[18,19]$. On the 
other hand, Dzwigaj et al. [20, 21] have proposed two-step postsynthesis method as an attractive alternative to obtain almost completely dealuminated beta zeolite with excellent dispersion of metal ions in the form of isolated mononuclear framework species. They used two-step postsynthesis method which consists of the creation of vacant T-atom sites by nitric acid treatment of parent beta zeolite and the subsequent incorporation of metal ions into framework of SiBEA zeolite by reaction with silanol groups associated with vacant T-atom sites.

In this work the two-step postsynthesis method was applied to obtain zeolite beta catalysts with isolated mononuclear $\mathrm{Cu}$ (II) incorporated into zeolite framework highly active in selective catalytic reduction of $\mathrm{NO}$ with $\mathrm{NH}_{3}$.

\section{Experimental}

\subsection{Catalyst preparation}

A TEABEA zeolite with atomic Si/Al ratio of 17 was treated i) in air at $823 \mathrm{~K}$ for $15 \mathrm{~h}$ to remove organic template and obtain an organic-free HAlBEA zeolite $(\mathrm{Si} / \mathrm{Al}=19)$ or ii) with nitric acid solution $\left(\mathrm{c}=13 \mathrm{~mol} \mathrm{dm}^{-3}, 353 \mathrm{~K}\right)$ over $4 \mathrm{~h}$ in order to remove aluminum species and obtain SiBEA zeolite. As obtained SiBEA with atomic Si/Al ratio of 1300 was washed several times with distilled water and dried at $368 \mathrm{~K}$ overnight. SiBEA zeolite was contacted with an aqueous copper nitrate solution which concentration varied from $1.96 \times$ $10^{-3}$ to $1.47 \times 10^{-2} \mathrm{~mol} \mathrm{dm}^{-3}$ and stirred for $24 \mathrm{~h}$ at $298 \mathrm{~K}$. Then, the suspension was stirred in the evaporator under vacuum of a water pump for $2 \mathrm{~h}$ at $333 \mathrm{~K}$, until water was evaporated. $\mathrm{Cu}$-containing SiBEA samples after calcination at $773 \mathrm{~K}\left(2 \mathrm{~K} \mathrm{~h}^{-1}\right)$ for $3 \mathrm{~h}$ were labeled as $\mathrm{C}$ $\mathrm{Cu}_{\mathrm{x}} \operatorname{SiBEA}($ with $\mathrm{x}=1-7.5 \mathrm{wt} \%$ ), where $\mathrm{C}$ state for calcined. 


\subsection{Catalysts characterization}

XRD profiles were recorded at room temperature on a PANalytical Empyrean diffractometer using the $\mathrm{CuK} \alpha$ radiation $(\lambda=154.05 \mathrm{pm})$.

Acidic properties of zeolite samples were determined by adsorption of pyridine (Py) followed by infrared spectroscopy. First, the samples were prepared in form of self-supported wafers of ca. $10 \mathrm{mg} \mathrm{cm}^{-2}$ and transferred into the IR cell. The activation procedure before pyridine sorption was as follows: (i) the wafers were calcined in a static atmosphere of $\mathrm{O}_{2}$ $\left(<3.0 \times 10^{4} \mathrm{~Pa}\right)$ at $723 \mathrm{~K}$ for $3 \mathrm{~h}$ and then outgassed under secondary vacuum at $573 \mathrm{~K}\left(10^{-3}\right.$ Pa) for $1 \mathrm{~h}$, (ii) the wafers were contacted at room temperature with gaseous Py (133 Pa) via a separate cell containing liquid pyridine. The spectra were recorded with a Bruker Vector 22 spectrometer (resolution $2 \mathrm{~cm}^{-1}, 128$ scans) after desorption at 423 and $573 \mathrm{~K}$ for $1 \mathrm{~h}$. The final spectra were obtained after subtraction of the spectrum recorded before pyridine adsorption from the one obtained after pyridine adsorption. The concentration of Brønsted and Lewis acidic sites was estimated using parameters calculated by Emeis [22].

The TPR- $\mathrm{H}_{2}$ measurements were carried out on an AutoChem 2910 apparatus (Micromeretics) equipped with a thermal conductivity detector (TCD) in the temperature range of $298-1250 \mathrm{~K}$ with a linear heating rate of $7 \mathrm{~K} \mathrm{~min}^{-1}$, hydrogen stream flow (5\% $\mathrm{H}_{2} / \mathrm{Ar}$ ) of $40 \mathrm{~cm}^{3} \mathrm{~min}^{-1}$ and samples weight of $0.1 \mathrm{~g}$.

\subsection{Catalytic measurements}

The activity of CuSiBEA catalysts in selective catalytic reduction (SCR) of NO with ammonia was measured in a conventional fixed-bed reactor. Temperature was measured inside the reactor with a thermocouple and controlled with an electronic controller (LUMEL RE19). The composition of reaction mixture was: $1000 \mathrm{ppm} \mathrm{NO}, 1000 \mathrm{ppm} \mathrm{NH}_{3}, 3.5$ vol.\% $\mathrm{O}_{2}$ and $\mathrm{He}$ as balance. The gas mixture was fed using calibrated electronic mass flow 
controllers (BETA-ERG). The total gas flow was $0.1 \mathrm{dm}^{3} \mathrm{~min}^{-1}$ and catalyst mass was $0.2 \mathrm{~g}$. Additional set of tests for several catalyst with addition of $500 \mathrm{ppm} \mathrm{SO}_{2}$ to substrate stream was carried out in order to study influence of $\mathrm{SO}_{2}$ presence on catalyst performance. The concentration of $\mathrm{NO}$ and $\mathrm{N}_{2} \mathrm{O}$ were analyzed by FTIR detectors (ABB 2000 AO series). The $\mathrm{NO}_{2}$ forming over SCR process was catalytically converted into NO with ABB Advance SCC-K converter before the exhaust gas was analyzed on the FTIR detectors. Thus, total amount of $\mathrm{NO}_{\mathrm{x}}$ was registered as to $\mathrm{NO}$ concentration.

Before the catalytic tests the samples were pretreated in oxygen/helium mixture $(0.1$ $\mathrm{dm}^{3} \min ^{-1}$ ) in the temperature range $298-798 \mathrm{~K}$ with a linear heating rate of $2 \mathrm{~K} \mathrm{~min}^{-1}$ and then for $1 \mathrm{~h}$ at $798 \mathrm{~K}$. The standard test conditions were $1 \mathrm{~h}$ at $423-773 \mathrm{~K}$ with increasing the reaction temperature every $50 \mathrm{~K}$ interval. The NO conversions were calculated from the measured concentration of nitric oxide. $\mathrm{N}_{2}$ selectivity was calculated based on following formula:

$N_{2}$ selectivity $(\%)=\frac{\left([\mathrm{NO}]_{\text {in }}-[\mathrm{NO}]_{\text {out }}\right)-\left[\mathrm{N}_{2} \text { o }\right]_{\text {out }}}{[\mathrm{NO}]_{\text {in }}-[\mathrm{NO}]_{\text {out }}} \times 100$

applied earlier by Moreno-Tost et al. [23] and Bin et al. [24].

The SCR reaction rates per gram of $\mathrm{Cu}$ were calculated from $\mathrm{NO}$ conversion with the equation [12]:

$R_{r}\left[\mathrm{~mol}_{\mathrm{NO}} \cdot g_{\mathrm{Cu}}{ }^{-1} \cdot \mathrm{s}^{-1}\right]=\frac{X_{N O} \times V\left[\mathrm{dm}^{3} \cdot \mathrm{s}^{-1}\right]}{m[g] \times 22.4\left[\mathrm{dm}^{3} \cdot \mathrm{mol}^{-1}\right]}$

where $R_{r}$ is reaction rate, $X_{N O} \mathrm{NO}$ conversion, $V$ flow rate and $m$ mass of $\mathrm{Cu}$.

\section{Results and discussions}

\subsection{XRD and FTIR studies}


Changes in the structure of zeolite BEA may be monitored by XRD measurements within a given series of zeolite samples taking into account the position of the diffraction reflex (302) at $2 \theta=22.5^{\circ}-22.6^{\circ}$ which shifts are the evidences of contraction and/or expansion of zeolites structure.

For HAlBEA zeolite the $\mathrm{d}_{302}$ spacing decreased from $3.943 \AA$ (with $2 \theta$ of $22.53^{\circ}$ ) to $3.911 \AA$ (SiBEA) (with $2 \theta$ of $22.72^{\circ}$ ) suggesting the zeolite structure contraction consistent with the dealumination of zeolite BEA. The impregnation of SiBEA with $\mathrm{Cu}$ precursor led to the increase of the $\mathrm{d}_{302}$ spacing, from $3.911 \AA$ (SiBEA) (with $2 \theta$ of $22.72^{\circ}$ ) to $3.926 \AA$ $\left(\mathrm{Cu}_{1.0} \mathrm{SiBEA}\right)$ (with $2 \theta$ of $\left.22.63^{\circ}\right)$ and to $3.933 \AA\left(\mathrm{Cu}_{2.0} \mathrm{SiBEA}\right)$ (with $2 \theta$ of $\left.22.59^{\circ}\right)$ (Fig. 1). The shifts of the main diffraction reflex positions may be interpreted as the expansion of the BEA structure and the incorporation of $\mathrm{Cu}$ ions into the framework of SiBEA zeolite, in agreement with the earlier study on MoSiBEA and CoSiBEA zeolites [25, 26].

Moreover, none of the studied diffractograms contained reflexes related to other phases, indicating no amorphization of zeolite structure and no formation of copper oxides crystallites.

Infrared spectroscopy is a powerful tool to examine the structure and the environment of active species in microporous materials, especially in case of surface hydroxyl groups. Figure 2 shows the FTIR spectra of SiBEA, $\mathrm{Cu}_{2.0} \mathrm{SiBEA}$ and $\mathrm{Cu}_{4.0} \mathrm{SiBEA}$ zeolites. For SiBEA three characteristic bands at 3736,3705 and $3520 \mathrm{~cm}^{-1}$ may be attributed to isolated internal, terminal internal and hydrogen-bonded silanol groups, respectively, situated at vacant T-atom sites forming hydroxyl nests $[14,27]$. The impregnation of SiBEA with copper nitrate solution led to a significant decrease of intensity of hydroxyl group bands at 3705 and $3520 \mathrm{~cm}^{-1}$, probably due to the reaction between $\mathrm{SiO}-\mathrm{H}$ and $\mathrm{Cu}^{2+}$ ions leading to the incorporation of copper into the framework of CuSiBEA zeolites, in line with earlier reports $[25,26]$ 


\subsection{Reducibility of the copper species determined by TPR}

Hydrogen consumption experiments were carried out to study copper species present in $\mathrm{C}-\mathrm{Cu}_{\mathrm{x}} \mathrm{SiBEA}$ zeolites. According to previous investigations on copper-containing zeolites, two types of reduction reaction pathways may be related to copper species. Generally, copper occurred as polynuclear extra-framework species is reduced to metallic copper in a direct reaction (1) with hydrogen $[13,28]$

$$
\mathrm{CuO}+\mathrm{H}_{2} \rightarrow \mathrm{Cu}^{0}+\mathrm{H}_{2} \mathrm{O}
$$

On the other hand $\mathrm{Cu}$ (II) species present as framework species or isolated ions in zeolites cavities are reduced in a two-steps process:

$$
\begin{aligned}
& \mathrm{Cu}^{2+}+1 / 2 \mathrm{H}_{2} \rightarrow \mathrm{Cu}^{+}+\mathrm{H}^{+} \\
& \mathrm{Cu}^{+}+1 / 2 \mathrm{H}_{2} \rightarrow \mathrm{Cu}^{0}+\mathrm{H}^{+}
\end{aligned}
$$

The presence of different copper species is strongly related to copper loading $[13,29]$. The higher the $\mathrm{Cu}$ content, the more cluster forms of copper and/or cooper oxides are expected.

The $\mathrm{H}_{2}$-TPR patterns of C-Cu${ }_{1.0} \mathrm{SiBEA}$ and $\mathrm{C}-\mathrm{Cu}_{2.0} \mathrm{SiBEA}$ (Fig. 3) exhibit one main peak at $480 \mathrm{~K}$ with a shoulder at $465 \mathrm{~K}$ as well as broad and low intense signal at $585 \mathrm{~K}$. The peaks at 465 and $480 \mathrm{~K}$ may be referred to the reduction of two types of mononuclear framework $\mathrm{Cu}(\mathrm{II})$ to $\mathrm{Cu}(\mathrm{I})$. The creation of two types of copper framework species is related to two different kinds of aluminum present in the parent BEA zeolite that have been removal upon the first step of postsynthesis procedure [14].

The second broad peak with a maximum at $585 \mathrm{~K}$ may arise from the partial reduction of $\mathrm{Cu}(\mathrm{I})$ species to $\mathrm{Cu}(0)$. The lower integral area of this signal than that seen at $465-480 \mathrm{~K}$ 
may suggest that reduction of copper(I) species to metallic form was not complete, as a result of strong interaction between SiBEA support and copper.

For $\mathrm{C}-\mathrm{Cu}_{4.0} \mathrm{SiBEA}$ sample containing a mixture of framework and extra-framework copper(II) species, much more intense signals were detected. Compared to $\mathrm{C}-\mathrm{Cu}_{1.0} \mathrm{SiBEA}$ and $\mathrm{C}-\mathrm{Cu}_{2.0} \mathrm{SiBEA}$, the additional signals appeared at 490 and $525 \mathrm{~K}$. The main reduction peak at $490 \mathrm{~K}$ may be related to the direct reduction of extra-framework octahedral $(\mathrm{Cu}$ (II) whereas the reduction peak at $525 \mathrm{~K}$ may be related to the reduction of copper oxides occurring in zeolite pores in line with earlier work on Cu containing BEA and ZSM-5 zeolites [13, 30].

Thus according to TPR results, the catalysts loaded with $\mathrm{Cu}$ up to 2 wt $\%$ contain predominantly mononuclear copper species. On the other hand, C-Cu${ }_{4.0} \mathrm{SiBEA}$ catalyst contains a mixture of framework and extra-framework $\mathrm{Cu}(\mathrm{II})$ species, while $\mathrm{C}-\mathrm{Cu}_{7.5} \mathrm{SiBEA}$ contains mainly copper oxides in extra-framework position.

\subsection{The nature and strength of acidic centers determined by FTIR}

Acidic properties of CuSiBEA zeolites were determined with FTIR experiments following pyridine sorption.

Figure 4 exhibits FTIR spectra of SiBEA, $\mathrm{Cu}_{2.0} \mathrm{SiBEA}$ and $\mathrm{Cu}_{4.0} \mathrm{SiBEA}$ after adsorption of pyridine at room temperature and desorption at $423 \mathrm{~K}$. For SiBEA five bands of very low intensity are seen at 1638, 1600, 1546, 1491 and $1448 \mathrm{~cm}^{-1}$, confirming the presence of a low number of strong Brønsted and Lewis acidic sites, in agreement with the studies of BEA and ZSM-5 zeolites [29, 31]. Presence of small amount of strong acidic centers is related to the remaining aluminum (ca. $0.1 \mathrm{wt} \%$ of initial $\mathrm{Al}$ content) that were not completely removed upon acid nitric treatment [14]. The introduction of copper into SiBEA framework led to the formation of a new type of Lewis acidic centers, confirmed by the appearance of the bands at 1610 and $1450 \mathrm{~cm}^{-1}$, consistent with other reports on copper containing zeolites [32, 
33]. Moreover, the introduction of copper decreased the concentration of Brønsted acidic sites, probably due to the exchange of $\mathrm{Cu}$ (II) ions with bridging acidic protons (Table $\mathbf{1}$ ). However, the lower frequencies of the band of pyridine for $\mathrm{Cu}_{2.0} \mathrm{SiBEA}$ and $\mathrm{Cu}_{4.0} \mathrm{SiBEA}$ zeolites at 1450 and $1611 \mathrm{~cm}^{-1}$ in comparison to parent BEA zeolite (bands at 1455 and 1622 $\mathrm{cm}^{-1}$ ) [14], indicate the lower strength of $\mathrm{Cu}(\mathrm{II})$ related to Lewis acidic sites that those arising from $\mathrm{Al}(\mathrm{III})$ species.

Furthermore, almost the same number of Lewis acidic centers was registered for both $\mathrm{Cu}_{2.0} \mathrm{SiBEA}$ and $\mathrm{Cu}_{4.0} \mathrm{SiBEA}$ catalysts, suggesting that only mononuclear copper species possess acidic character in contrast to extra-framework copper species. This conclusion is in line with reports of $\mathrm{Cu}$ ion-exchanged zeolites $[34,35]$.

\subsection{Catalytic activity of $C u_{x}$ SiBEA zeolites}

The performance of the $\mathrm{Cu}_{\mathrm{x}} \mathrm{SiBEA}$ zeolites differs with reaction temperature, copper loading and the form of copper species present in these catalysts. As was reported earlier in our work [36], SiBEA support exhibited very low activity in $\mathrm{NH}_{3}-\mathrm{SCR}$, with $\mathrm{NO}$ conversion lower than $15 \%$ in the whole temperature range. The introduction of copper into zeolite structure resulted in a significant increase of NO conversion for all catalysts, indicating that copper species are active sites in $\mathrm{NH}_{3}$-SCR reaction.

In low temperature range (423 - $573 \mathrm{~K})$ all catalysts showed excellent activity with NO conversion of $90 \%$ (Fig. 5). The highest NO conversion - $100 \%$ - was registered for $\mathrm{Cu}_{7.5} \mathrm{SiBEA}$ zeolite at $523 \mathrm{~K}$. Such remarkable activity at low temperature is not very often reported. Generally, the highest activity of $\mathrm{Cu}$-containing zeolites was observed at moderate temperatures $(573-673 \mathrm{~K})[13,34]$. For $\mathrm{Cu}_{4.0}$ SiBEA and $\mathrm{Cu}_{7.5} \operatorname{SiBEA}$ zeolites after increasing the reaction temperature up to $573 \mathrm{~K}$, NO conversion started to decrease, especially at high temperature range $(673-773 \mathrm{~K})$ (from $\sim 80 \%$ to $\sim 10 \%)$. On the other hand, 
$\mathrm{Cu}_{1.0} \mathrm{SiBEA}$ and $\mathrm{Cu}_{2.0} \mathrm{SiBEA}$, containing predominantly mononuclear $\mathrm{Cu}(\mathrm{II})$ species, stayed much more active, with NO conversion around $50 \%$ at $773 \mathrm{~K}$.

Similar behavior of copper promoted zeolites was observed earlier. Wang et al. [37] and Pereda-Ayo et al. [13] explained the decrease in $\mathrm{NO}$ conversion in $\mathrm{NH}_{3}$-SCR at moderate and high temperatures by oxidation of ammonia with $\mathrm{O}_{2}$ or the appearance of secondary reaction

$$
4 \mathrm{NO}+4 \mathrm{NH}_{3}+3 \mathrm{O}_{2}=4 \mathrm{~N}_{2} \mathrm{O}+6 \mathrm{H}_{2} \mathrm{O}
$$

They mentioned also that ammonia oxidation was strongly favored by polynuclear copper species, such as copper oxides. These conclusions are consistent with our experimental results.

Figure 6 reveals $\mathrm{N}_{2} \mathrm{O}$ formation as a side-product in SCR process. The application of $\mathrm{Cu}_{4.0} \mathrm{SiBEA}$ catalyst, containing the mixture of framework and extra-framework copper species, and $\mathrm{Cu}_{7.5} \mathrm{SiBEA}$ catalyst, containing mainly copper oxides, resulted in the formation of large amounts of $\mathrm{N}_{2} \mathrm{O}$ in outgases stream, indicating the oxidation of ammonia with gaseous oxygen. However, when $\mathrm{Cu}_{1.0} \mathrm{SiBEA}$ catalyst was used, a very low formation of $\mathrm{N}_{2} \mathrm{O}$ was observed in whole studied temperature range. This unique performance may be related to the presence of predominantly mononuclear $\mathrm{Cu}(\mathrm{II})$ species, occurring in the framework of SiBEA zeolite. Our results are in line with the studies on copper exchanged ZSM-5, Beta, SAPO-34 and chabazite zeolites where mononuclear $\mathrm{Cu}^{2+}$ ions situated in the exchanged positions were responsible for high $\mathrm{NO}$ conversion and $\mathrm{N}_{2}$ selectivity [12, 13, 33, 37, 38].

In Figure 7 the $\mathrm{N}_{2}$ selectivity is given, calculated from $\mathrm{NO}$ conversion and $\mathrm{N}_{2} \mathrm{O}$ formation according to equation (1). It may be seen that for $\mathrm{Cu}_{1.0} \mathrm{SiBEA}$ catalyst, $\mathrm{N}_{2}$ selectivity was the highest of all studied samples and always above $91 \%$. With the increasing copper content and increasing the reaction temperature, selectivity to $\mathrm{N}_{2}$ dropped. As may be 
expected, the poorest $\mathrm{N}_{2}$ selectivity $(\sim 65 \%)$ was registered for $\mathrm{Cu}_{7.5} \mathrm{SiBEA}$ catalyst at high temperature range.

In order to discuss catalysts activity as a function of active material loading reaction rates for all studied catalysts per gram $\mathrm{Cu}$ were calculated. The results are displayed in Figure 8. They clearly show that the most active species in $\mathrm{NH}_{3}-\mathrm{SCR}$ are isolated framework $\mathrm{Cu}$ (II) species, predominantly present in $\mathrm{Cu}_{1.0} \mathrm{SiBEA}$ catalyst.

\subsection{The influence of $\mathrm{SO}_{2}$ addition on catalytic activity of $\mathrm{Cu}_{x} \mathrm{SiBEA}$ zeolites}

Combustion of coal as well as liquid fuels containing sulfur even at low concentration, results in the presence of $\mathrm{SO}_{2}$ and $\mathrm{SO}_{3}$ in the exhaust gases. Sulfur oxides may strongly influence catalyst performance in selective catalytic reduction with ammonia [39, 40]. In order to check the resistance of our catalysts towards sulfur poisoning, a new set of catalytic tests with the addition of 500 ppm of $\mathrm{SO}_{2}$ was carried out (Fig. 9).

The presence of sulfur dioxide led to severe decrease in NO conversion at low temperature for both $\mathrm{Cu}_{1.0} \mathrm{SiBEA}$ and $\mathrm{Cu}_{4.0} \mathrm{SiBEA}$ catalyst. The NO conversion is low probably due to reaction of sulfur dioxide and copper species and/or the formation of ammonia sulphates. However, when reaction temperature was raised to $623 \mathrm{~K}$ a significant increase in NO conversion was observed. Moreover, for $\mathrm{Cu}_{1.0} \mathrm{SiBEA}$ catalyst activity at $673-$ $723 \mathrm{~K}$ was very similar to that observed for the test without $\mathrm{SO}_{2}$. This remarkable activity may be ascribed to the presence of framework mononuclear copper(II) which seen to be more resistant to sulfur contamination than extra-framework polynuclear copper.

\section{Conclusions}

XRD, TPR and FTIR studies revealed the successful copper incorporation into SiBEA zeolite framework with two-step postsynthesis method for low $\mathrm{Cu}$ content (up to 2 wt \%). For 
the catalysts containing 4 and $7.5 \mathrm{wt} \%$ of $\mathrm{Cu}$, a mixture of framework and extra-framework copper species was detected.

Pyridine sorption allowed to establish that the incorporation of copper(II) into zeolite framework led to the formation of new Lewis acidic sites with moderate strength.

The application of $\mathrm{Cu}_{1.0} \mathrm{SiBEA}$ zeolites with predominantly framework mononuclear copper(II) for selective catalytic reduction with ammonia resulted in high activity in the wide temperature range, with simultaneous $\mathrm{N}_{2}$ selectivity above $90 \%$.

The formation of $\mathrm{N}_{2} \mathrm{O}$ increased with $\mathrm{Cu}$ content due to the presence in $\mathrm{Cu}_{\mathrm{x}} \mathrm{SiBEA}$ zeolites of copper oxides which promote rather ammonia oxidation in moderate and high temperature than NO reduction, leading to poor selectivity to $\mathrm{N}_{2}$ and low NO conversion.

\section{Acknowledgment}

The project was funded by the National Science Centre Poland $(\mathrm{NCN})$ on the basis of the decision number UMO-2012/07/N/ST5/00171 - "PRELUDIUM” grant (R.B., S.D.)

Teresa Grzybek would like to acknowledge for the financial support of AGH grant: 11.11.210.213. 


\section{References}

[1] P. Forzatti, Appl. Catal. A 222 (2001) 221-236.

[2] P. Forzatti, Catal. Today 62 (2000) 51-65.

[3] P. Balle, B. Geige, D. Klukowski, M. Pignatelli, S. Wohnrau, M. Menzel, I. Zirkwa, G. Brunklaus, S. Kureti, Appl. Catal. B 91 (2009) 587-595.

[4] R. Moreno-Tost, M.L. Oliveira, D. Eliche-Quesada, J. Jiménez-Jiménez, A. JiménezLópez, E. Rodríguez-Castellón, Chemosphere 72 (2008) 608-615.

[5] M. Motak, Catal. Today 137 (2008) 247-252.

[6] M. Jabłonska, A.E. Palomares, L. Chmielarz, Chem. Eng. J. 231 (2013) 273-280.

[7] T. Grzybek, Catal. Today 119 (2007) 125-132.

[8] P.S. Metkar, M.P. Harold, V. Balakotaiah, Chem. Eng. Sci. 87 (2013) 51-66.

[9] S.A. Yashnik, A.V. Salnikov, N.T. Vasenin, V.F. Anufrienko, Z.R. Ismagilov, Catalysis Today 197 (2012) 214-227

[10] C. He, Y. Wang, Y. Cheng, C.K. Lambert, R.T. Yang, Appl. Catal. A 368 (2009) 121126.

[11] M. Colombo, I. Nova, E. Tronconi, Catal.Today 151 (2010) 223-230.

[12] J. Xue, X. Wang, G. Qi, J. Wang, M. Shen, W. Li, J. Catal. 297 (2013) 56-64.

[13] B. Pereda-Ayo, U. De La Torre, M. José Illán-Gómez ,A. Bueno-López, J.R. GonzálezVelasco, Appl. Catal. B 147 (2014) 420- 42

[14] R. Baran, Y. Millot, T. Onfroy, J.-M. Krafft, S. Dzwigaj, Micropor. Mesopor. Mater. 163 (2012) 122-130.

[15] P.G. Blakeman, E.M. Burkholder, H.-Y. Chen, J.E. Collier, J.M. Fedeyko, H. Jobson, R.R. Rajaram, Cat. Today 231 (2014) 56-63.

[16] A. Subbiah, B.K. Cho, R.J. Blint, A. Gujar, G.L. Price, J.E. Yie, Appl. Catal. B 42 (2003) 155-178. 
[17] J.-H. Park, H.J. Park, J.H. Baik, I.-S. Nam, C.-H. Shin, J.-H. Lee, B.K. Cho, S.H. Oh, J. Catal. 240 (2006) 47-57.

[18] Q. Ye, L. Wang, R.T. Yang, Appl. Catal. A 427-428 (2012) 24-34.

[19] D. Wang, Y. Jangjou, Y. Liu, M.K. Sharma, J. Luo, J. Li, K. Kamasamudram, W.S. Epling, Appl. Catal. B (2014), http://dx.doi.org/10.1016/j.apcatb.2014.10.020

[20] J. Janas, J. Gurgul, R.P. Socha, S. Dzwigaj, Appl. Catal. B 91 (2009) 217-224.

[21] F. Tielens, M. Trejda, M. Ziolek, S. Dzwigaj, Catal. Today 139 (2008) 221-226.

[22] C.A. Emeis, J. Catal. 141 (1993) 347-354.

[23] R. Moreno-Tost, J. Santamaria-Gonzalez, P. Maireles-Torres, E. Rodriguez-Castellon, A. Jiménez-López, Appl. Catal. B 38 (2002) 51-60.

[24] F. Bin, C. Song, G. Lv, J. Song, X. Cao, H. Pang, K. Wang, J. Phys. Chem. C 116 (2012) $26262-26274$.

[25] R. Baran, F. Averseng, Y. Millot, T. Onfroy, S. Casale, S. Dzwigaj, J. Phys. Chem. C 118 (2014) 4143-4150.

[26] R. Baran, T. Onfroy, S. Casale, S. Dzwigaj, J. Phys. Chem. C 118 (2014) 20445-20451.

[27] S. Dzwigaj, P. Massiani, A. Davidson, M. Che, J. Mol. Catal. A 155 (2000) 169-182.

[28] C. Torre-Abreu, C. Henriques, F.R. Ribeiro, G. Delahay, M.F. Ribeiro, Catal. Today 54 (1999) 407-418.

[29] I.O. Ali, Mater. Sci. Eng. A 459 (2007) 294-302.

[30] L. Xu, C. Shi, Z. Zhang, H. Gies, F.-Shou Xiao, D. De Vos, T. Yokoi, X. Bao, M. Feyen, S. Maurer, B. Yilmaz, U. Müller, W. Zhang, Micropor. Mesopor. Mater.200 (2014) 304-310. [31] Y. Oumi, R. Mizuno, K. Azuma, S. Nawata, T. Fukushima, T. Uozumi, T. Sano, Micropor. Mezopor. Mater. 49 (2001) 103-109

[32] P. Manjunathan, S. P. Maradur, A.B. Halgeri, Ganapati V. Shanbhag, J. Mol. Catal. A $396(2015)$ 47-54. 
[33] A. Sultana, T. Nanba, M. Haneda, M. Sasaki, H. Hamada, Appl. Catal. B 101 (2010) 6167.

[34] F. Benaliouche, Y. Boucheffa, P. Ayrault, S. Mignard, P. Magnoux, Micropor. Mesopor. Mater. 111 (2008) 80-88.

[35] J. Engeldinger, C. Domke, M. Richter, U. Bentrup, Appl. Catalysis A 382 (2010) 303311.

[36] R. Baran, T. Onfroy, T. Grzybek, S. Dzwigaj, Appl. Catal. B 136- 137 (2013) 186-192.

[37] D. Wang, L. Zhang, J. Li, K. Kamasamudram, W.S. Epling, Catal. Today 231 (2014) 6474.

[38] O. Mihai, C.R. Widyastuti, S. Andonova, K. Kamasamudram, J. Li, S.Y. Joshi, N.W. Currier, A. Yezerets, L. Olsson, J. Catal. 311 (2014) 170-181.

[39] Y. Cheng, C. Lambert, D.H. Kim, J.H. Kwak, S.J. Cho, C.H.F. Peden, Catal Today 151 (2010) 266-270.

[40] X. Liu, X. Wu, D. Weng, Z. Si, Catal. Comm. 59 (2015) 35-39. 


\section{Figure captions}

Figure 1. XRD patterns of HAIBEA, SiBEA, $\mathrm{Cu}_{1.0} \mathrm{SiBEA}, \mathrm{Cu}_{2.0} \mathrm{SiBEA}, \mathrm{Cu}_{4.0} \mathrm{SiBEA}$ and $\mathrm{Cu}_{7.5} \mathrm{SiBEA}$ zeolites.

Figure 2. FTIR spectra of $\mathrm{SiBEA}, \mathrm{Cu}_{2.0} \mathrm{SiBEA}, \mathrm{Cu}_{4.0} \mathrm{SiBEA}$ zeolites.

Figure 3. TPR patterns of $\mathrm{C}-\mathrm{Cu}_{1.0} \mathrm{SiBEA}, \mathrm{C}-\mathrm{Cu}_{2.0} \mathrm{SiBEA}, \mathrm{C}-\mathrm{Cu}_{4.0} \mathrm{SiBEA}$ and $\mathrm{C}-\mathrm{Cu}_{7.5} \mathrm{SiBEA}$ zeolites.

Figure 4. FTIR spectra recorded at room temperature of $\mathrm{SiBEA}, \mathrm{Cu}_{2.0} \mathrm{SiBEA}$ and $\mathrm{Cu}_{4.0} \mathrm{SiBEA}$ zeolites after adsorption of pyridine $(133 \mathrm{~Pa})$ for $1 \mathrm{~h}$ at room temperature and desorption at $423 \mathrm{~K}$ for $1 \mathrm{~h}$.

Figure 5. $\mathrm{NO}$ conversion in $\mathrm{SCR}$ of $\mathrm{NO}$ with $\mathrm{NH}_{3}$ on $\mathrm{Cu}_{1.0} \mathrm{SiBEA}, \mathrm{Cu}_{2.0} \mathrm{SiBEA}, \mathrm{Cu}_{4.0} \mathrm{SiBEA}$ and $\mathrm{Cu}_{7.5} \mathrm{SiBEA}$ zeolite catalysts.

Figure 6. $\mathrm{N}_{2} \mathrm{O}$ formation in $\mathrm{SCR}$ of $\mathrm{NO}$ with $\mathrm{NH}_{3}$ on $\mathrm{Cu}_{1.0} \mathrm{SiBEA}, \mathrm{Cu}_{2.0} \mathrm{SiBEA}, \mathrm{Cu}_{4.0} \mathrm{SiBEA}$ and $\mathrm{Cu}_{7.5} \mathrm{SiBEA}$ zeolite catalysts.

Figure 7. $\mathrm{N}_{2}$ selectivity in $\mathrm{SCR}$ of $\mathrm{NO}$ with $\mathrm{NH}_{3}$ on $\mathrm{Cu}_{1.0} \mathrm{SiBEA}, \mathrm{Cu}_{2.0} \mathrm{SiBEA}_{1} \mathrm{Cu}_{4.0} \mathrm{SiBEA}$ and $\mathrm{Cu}_{7.5} \mathrm{SiBEA}$ zeolites catalysts.

Figure 8. Catalytic activity of $\mathrm{Cu}_{1.0} \mathrm{SiBEA}, \mathrm{Cu}_{2.0} \mathrm{SiBEA}, \mathrm{Cu}_{4.0} \mathrm{SiBEA}$ and $\mathrm{Cu}_{7.5} \mathrm{SiBEA}$ zeolite catalysts in $\mathrm{SCR}$ of $\mathrm{NO}$ with $\mathrm{NH}_{3}-$ Reaction rate per gram of $\mathrm{Cu}$.

Figure 9. $\mathrm{NO}$ conversion in $\mathrm{SCR}$ of $\mathrm{NO}$ with $\mathrm{NH}_{3}$ on $\mathrm{Cu}_{1.0} \mathrm{SiBEA}$ and $\mathrm{Cu}_{4.0} \mathrm{SiBEA}$ zeolite catalysts without and with addition of $500 \mathrm{ppm}$ of $\mathrm{SO}_{2}$. 
Table 1. Amounts of Brønsted and Lewis Acidic Centers on SiBEA, $\mathrm{Cu}_{2.0} \mathrm{SiBEA}$ and $\mathrm{Cu}_{4.0} \mathrm{SiBEA}$.

\begin{tabular}{ccc}
\hline Sample & $\begin{array}{c}\text { Brønsted acidic centers } \\
\left(\mu \mathrm{mol} \mathrm{g}^{-1}\right)\end{array}$ & $\begin{array}{c}\text { Lewis acidic centers } \\
\left(\mu \mathrm{mol} \mathrm{g}^{-1}\right)\end{array}$ \\
\hline SiBEA & 6 & 2 \\
$\mathrm{Cu}_{2.0} \mathrm{SiBEA}$ & 3 & 52 \\
$\mathrm{Cu}_{4.0} \mathrm{SiBEA}$ & 1 & 50 \\
\hline
\end{tabular}




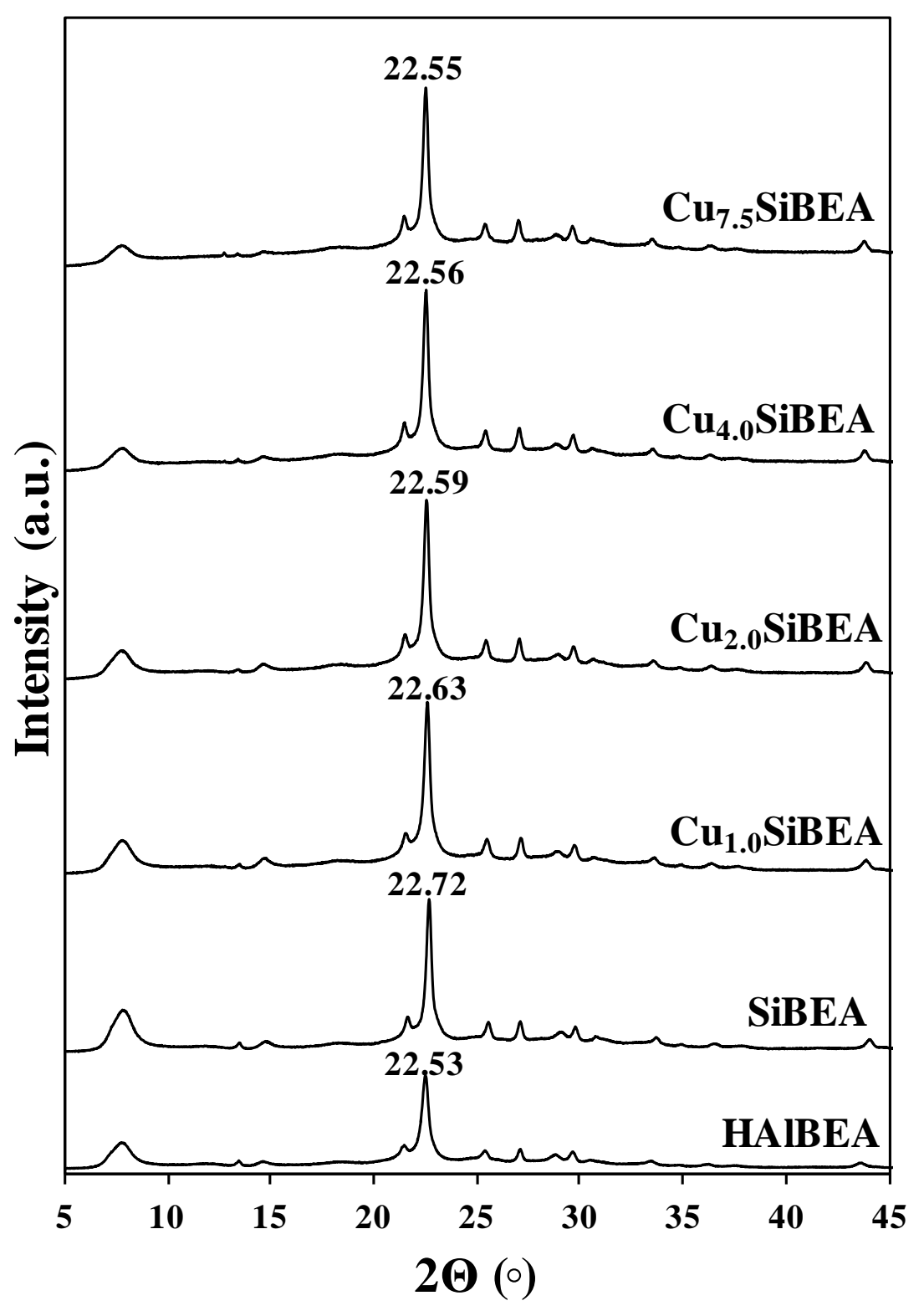

Figure 1 


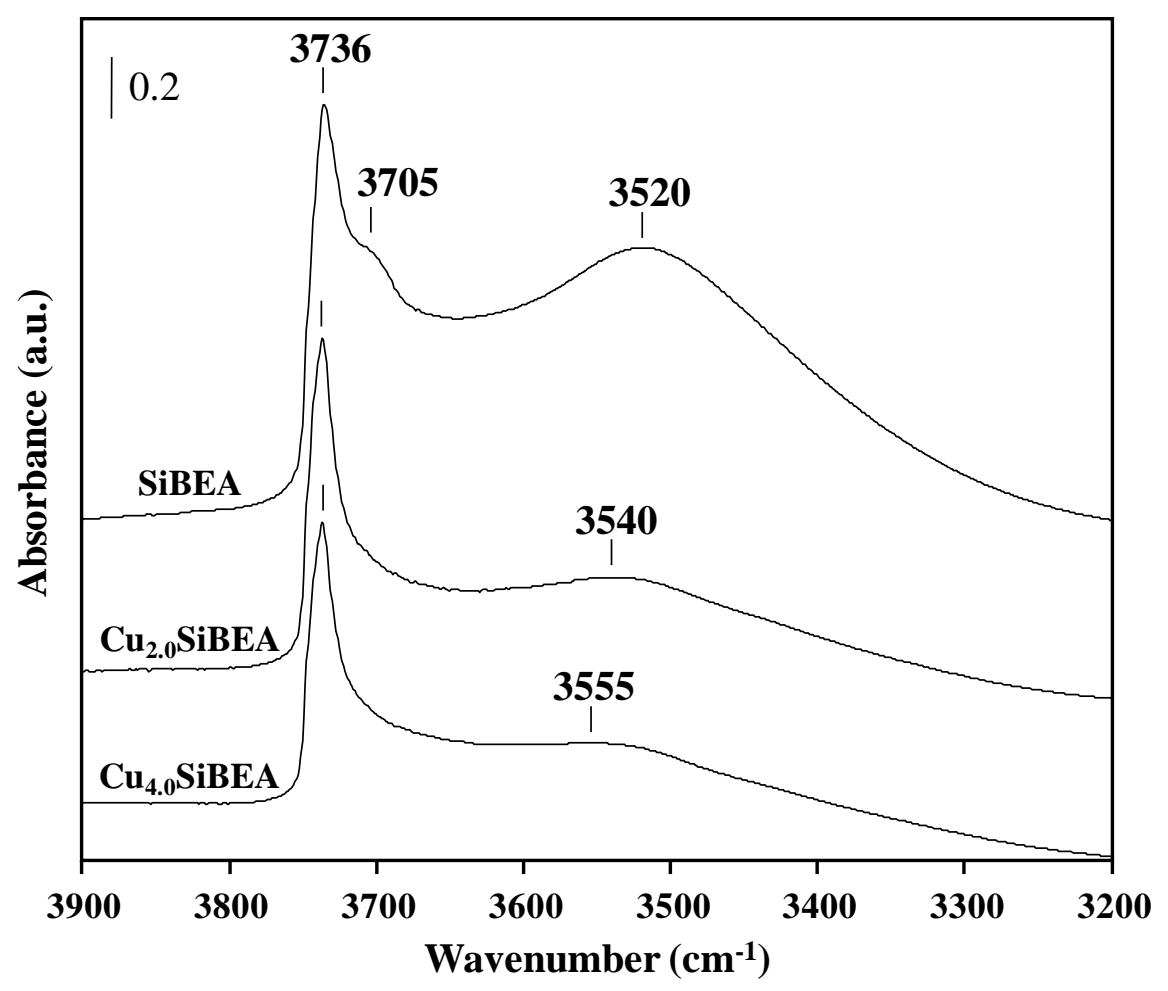

Figure 2 


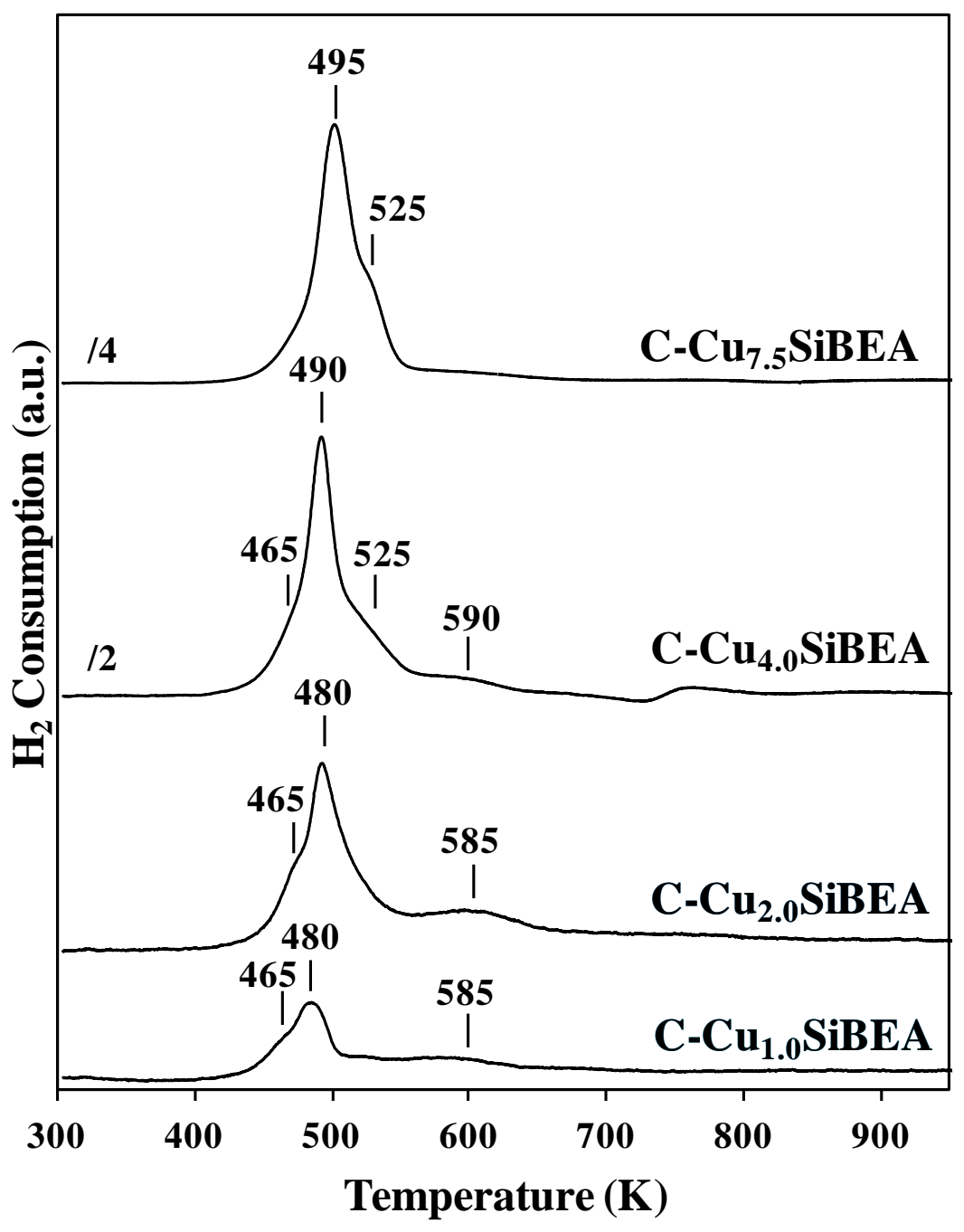

Figure 3 


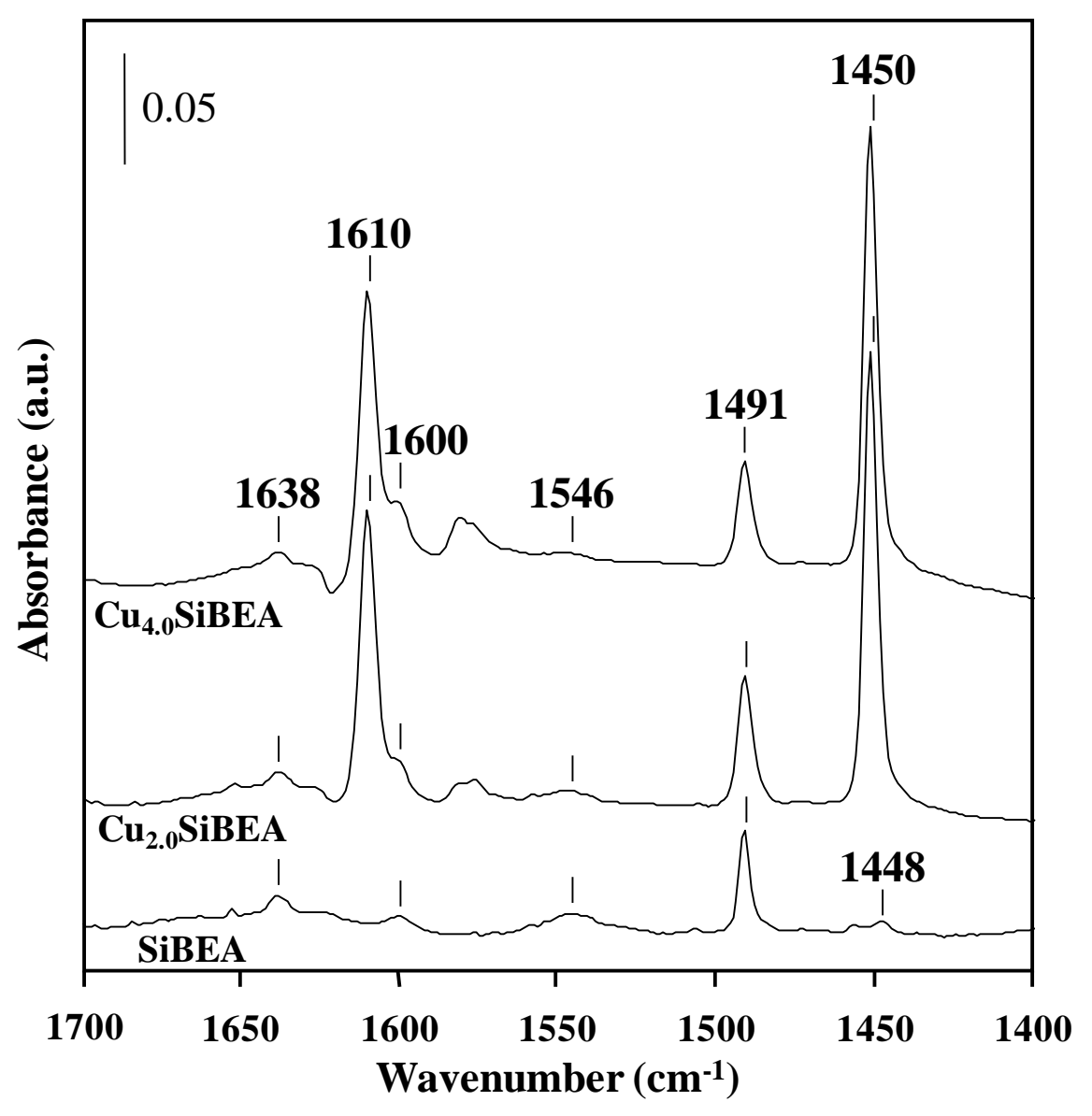

Figure 4 


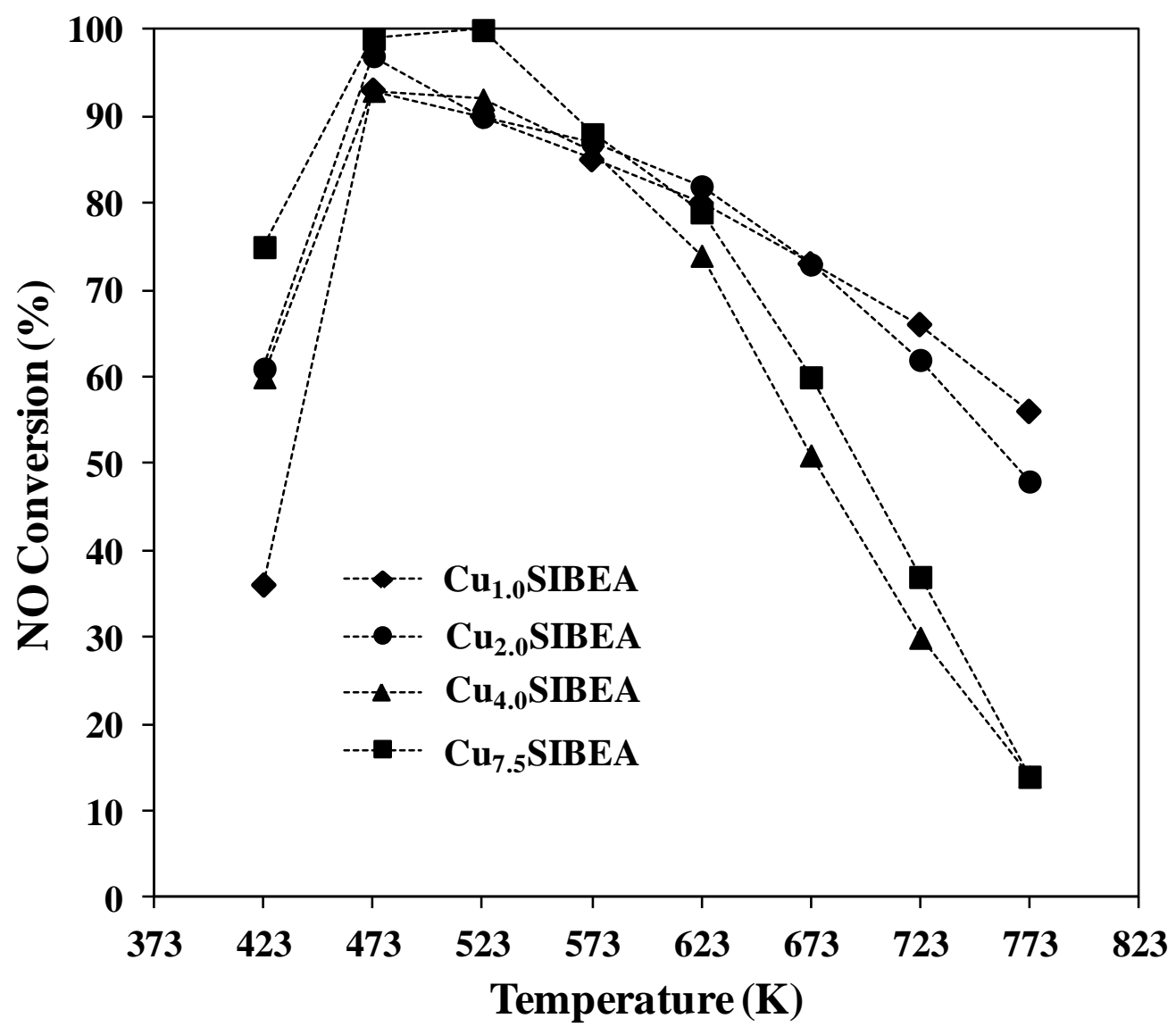

Figure 5 


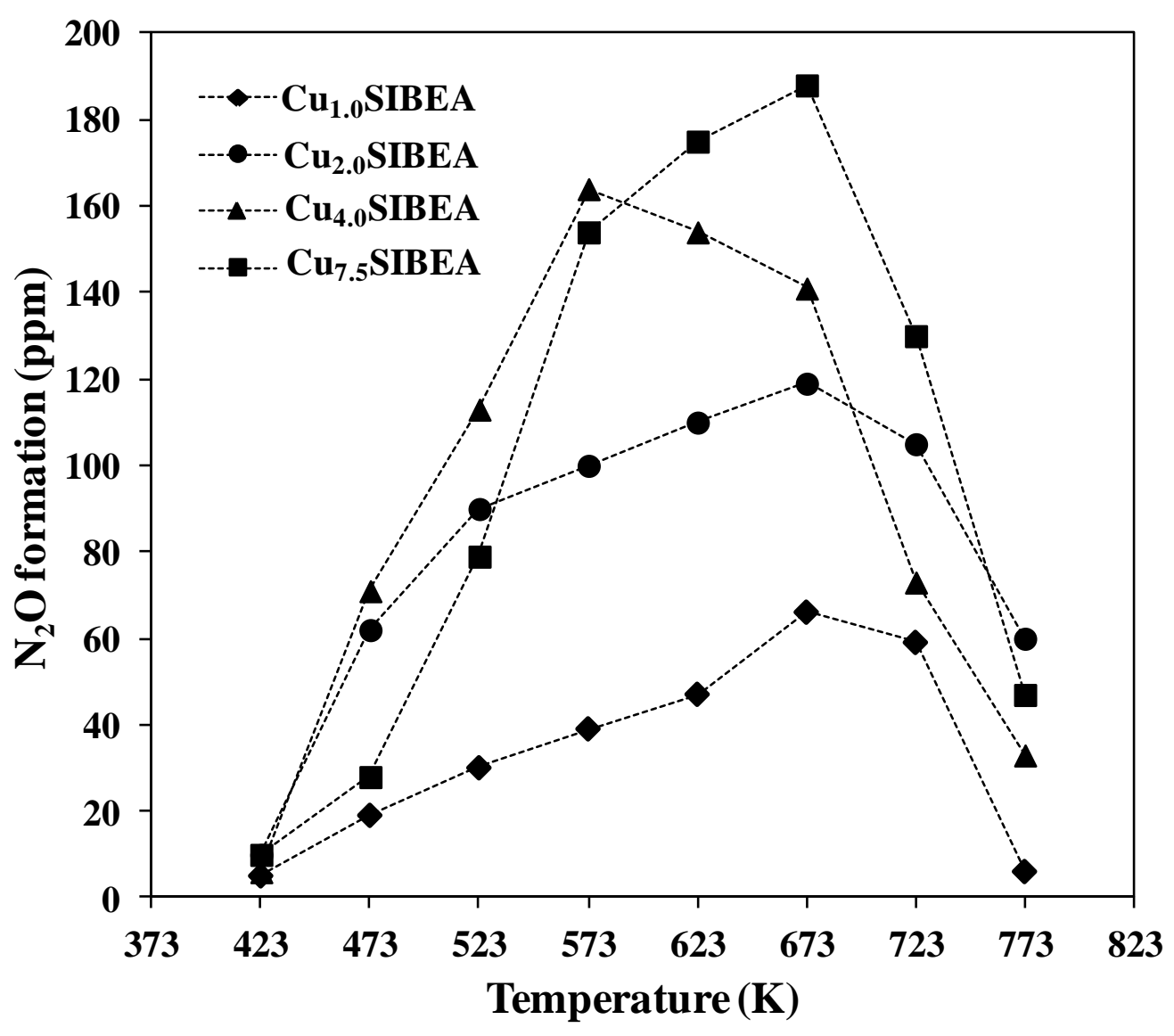

Figure 6 


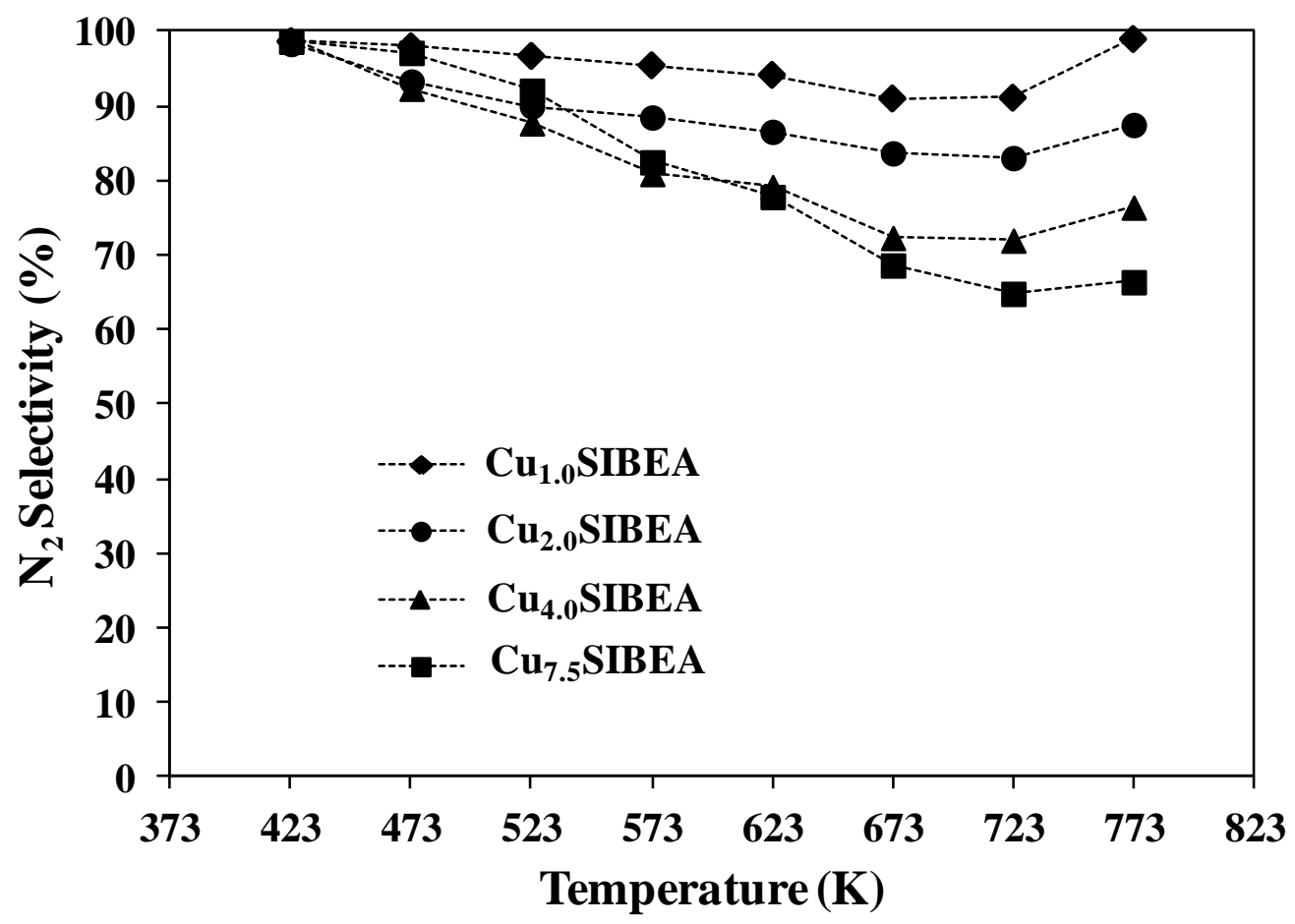

Figure 7 

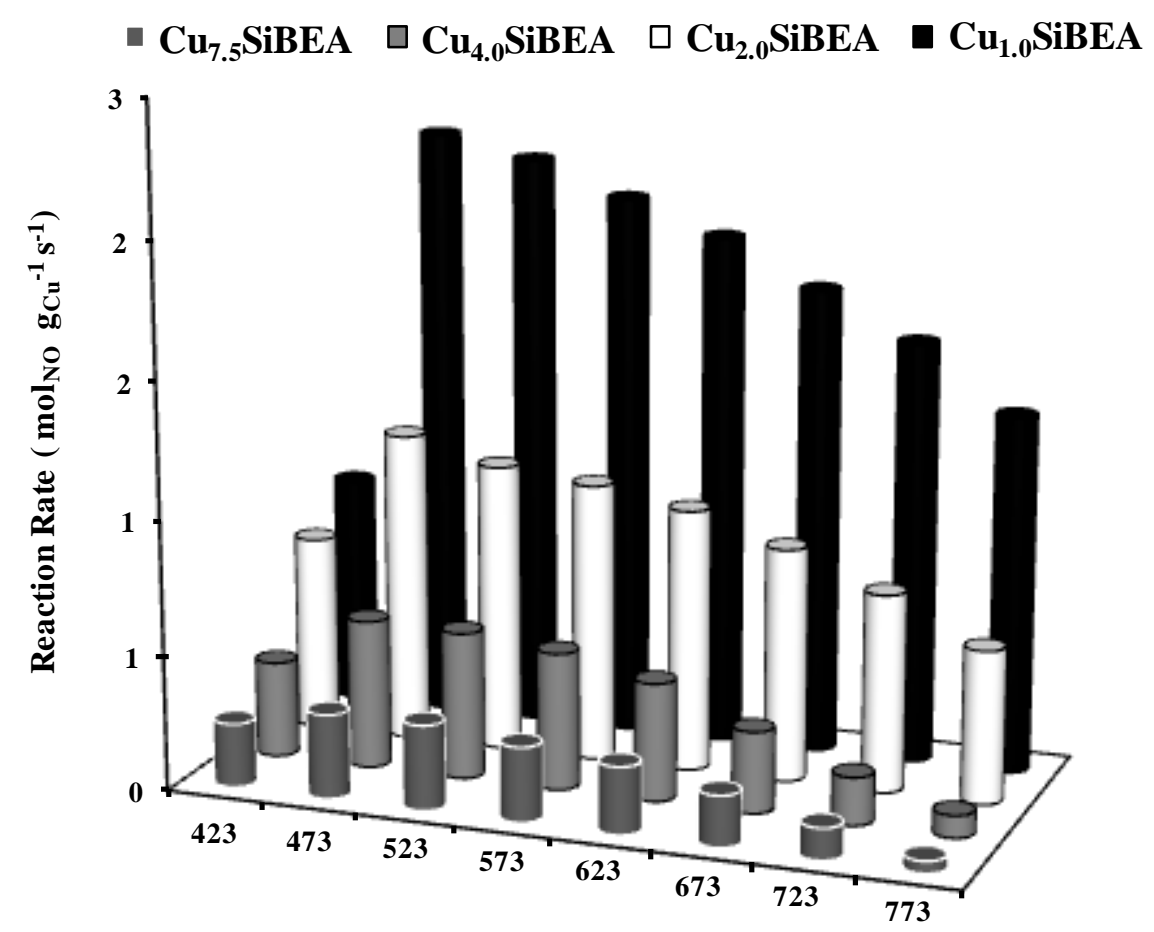

Temperature (K)

Figure 8 


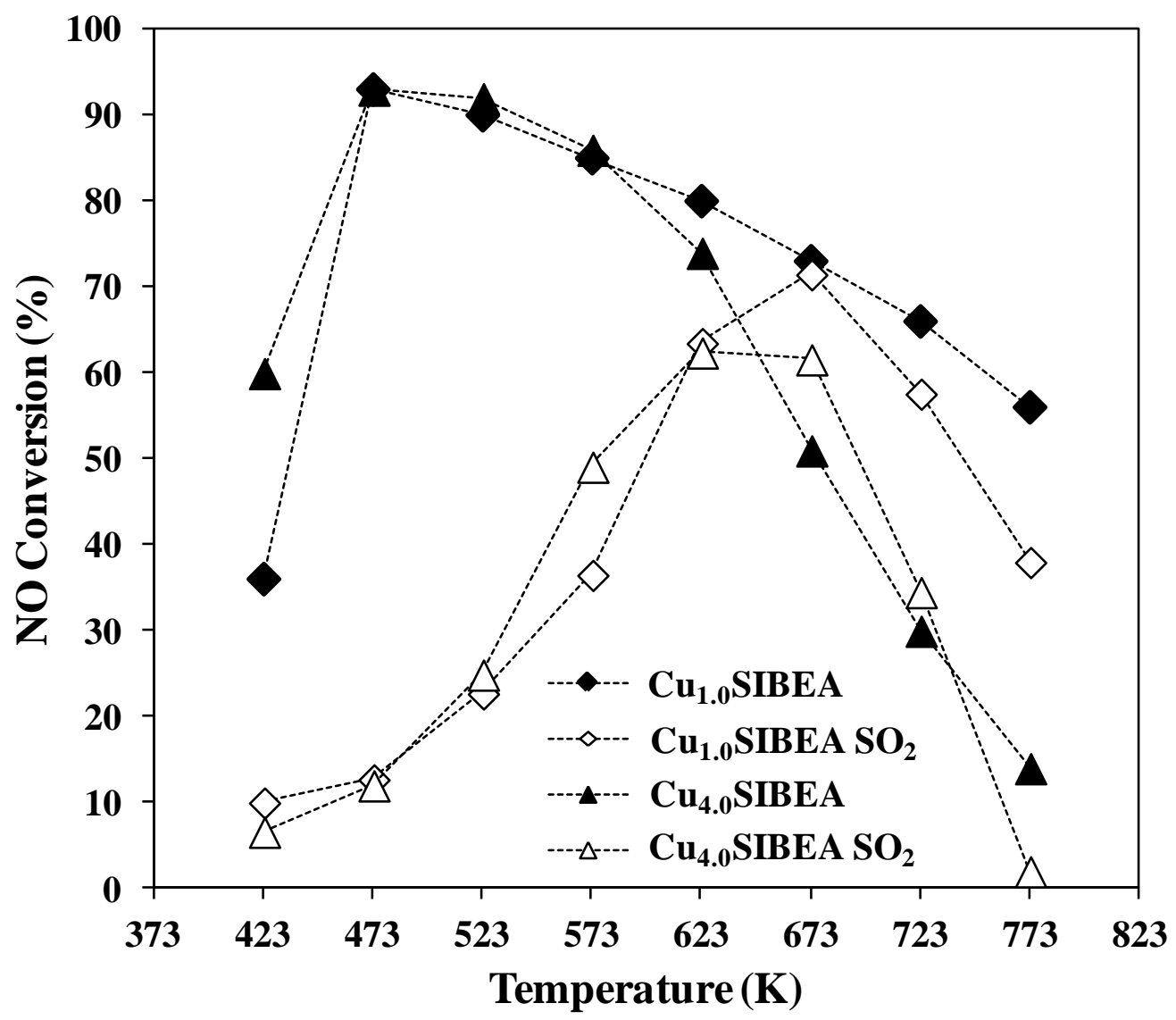

Figure 9 